\title{
A New Species of Eurychilella (Hemiptera:Miridae) ${ }^{1}$
}

\author{
J. Maldonado Capriles ${ }^{2}$
}

\begin{abstract}
Eurychilella hemiclava from Colombia is described, illustrated, and compared with the other species in the genus. A key is provided to separate this genus from three allied genera.
\end{abstract}

\section{INTRODUCTION}

From material collected by Dr. J. A. Ramos in Colombia, I herein describe a new species of Eurychilella, a Neotropical bryocorine genus. Carvalho ${ }^{3}$ monographed this genus and gave a key to the seven known species. From dorsal view the eyes of these species have the caudal external angle extended and pointing caudad, and on lateral aspect the eye is C-shaped. Eurychilella Reuter keys out with Eccritotarsus Stal. Two other genera, Panamacoris Carvalho and Penha Gomes ${ }^{4}$ and Eurychiloides Carvalho and Penha Gomes ${ }^{4}$ have similarly pointed eyes. These two genera are not included in Carvalho's key to the genera of the Bryocorinae $^{5}$ as they were described later. A partial key separating these four genera follows:

1. Eyes circular from above; II antennal segment longer than head across eyes; scutellum with fine punctures; hemelytra wider across

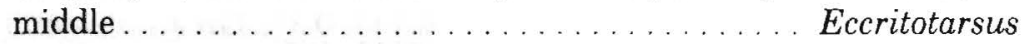

Eyes from above with posterior external angle sharp and pointing caudad; II antennal segment shorter than head across eyes; hemelytra variable, scutellum different .............. 2

2. Beak reaching metacoxae; collar gibbose, not extending over base of head; hemelytra parallel sided ............ Panamacoris

Beak barely reaching mesocoxae; collar not gibbose .......... 3

3. Body parallel-sided; scutellum smooth; males with two small caudad

${ }^{1}$ Manuscript submitted to Editorial Board February 2, 1983.

2 Entomologist, Department of Plant Protection, Agricultural Experiment Station, Mayagüez Campus, University of Puerto Rico, Río Piedras, P.R.

${ }^{3}$ Carvalho, J. C. M., 1953. Neotropical Miridae, LXVIII: genus Eurychilella Reuter with descriptions of four new species, Rev. Brasil. Biol. 13 (4): 347-53.

${ }^{4}$ Carvalho, J. C. M. e Italia da Penha Gomes, 1971. Mirideos Neotropicais, CXXIV: Quatro géneros e Dezesseis espécies novos da Tribg Bryocorini Douglas \& Scott (Hemiptera). An. Acad. Brasil. Ciénc. 43 (2):461-78.

${ }^{5}$ Carvalho, J. C. M., 1955. Chaves para os géneros de Mirideos do Mundo (Hemiptera) Bol. Mus. Paraense Emilio Goeldi. 11 (2): 1-151. 
projections on posterior margin of pronotum; collar not extending over base of head..................... Eurychiloides Body oval; scutellum pitted; collar extending over base of head Eurychilella

\section{Eurychilella hemiclava Maldonado NEW SPECIES}

Male. Above mostly grayish yellow. Head pale fuscous, eyes black: clypeus brownish, gena with small brown spot below antenna; sterna and pleurae dark gray; abdomen black. Pronotum unmarked; scutellum mostly grayish brown, black basally and along margins; clavus black in a wedge-shaped fashion to about midlength, the black turning to brown apically; corium with an irregular brownish spot across about level to apex of clavus; embolium unmarked; cuneus brownish with black apical angles; vein of membrane brownish. Legs: procoxa, metacoxa, and trochanters castaneous; mesocoxa grayish; profemur castaneous, protibia dark gray; mid legs castaneous, tibia dark gray apically; metafemur castaneous on basal half, apical half dark gray; metatibia dark gray; tarsi yellowish (fig. 5).

Head: width across eyes 0.65 , interocular space 0.34 , length 0.2 ; eyes from above with posterior outer angle produced caudad, eye on lateral aspect $\mathrm{C}$-shaped. Antenna: I, 0.25 ; II, 0.5 ; others missing; very scarcely short pilose. Beak barely reaching middle coxae. Pronotum: collar and posterior lobe pitted; calli smooth, slightly elevated; collar slightly extending over base of head (fig 4); length 0.64, width at humeral angles 0.89 . Scutellum pitted, length 0.30 , width 0.37 . Greatest width across forewings 1.10; cuneus length 0.5 , width 0.25 . Genital segments as in figures 1 to 3 . Overall length $2.3 \mathrm{~mm}$.

Female. Mostly same colors and pattern of male; cuneus grayish yellow; sterna with apical half brownish, thus looking banded; last segment brownish, ovipositor black.

Head: width across eyes 0.66 , interocular space 0.31 , length 1.15 . Antenna: I, 0.2; II, 0.47. Eyes as in male. Pronotum: length 0.65, width 1.0; collar and posterior lobe pitted; calli small, round, slightly elevated, smooth; posterior margin slightly indented above scutellum. Scutellum length 0.25 , width 0.35 . Greater width across forewings 1.2 ; cuneus length 0.6 , width 0.3 . Overall length $2.66 \mathrm{~mm}$.

Holotype. Male, Colombia, Apiay, Meta, 14 July 1965, J. A. Ramos collector, NMNH Cat No. 100696. Allotype. Female, Colombia, Quetame, Cundinamarca, 12 October 1965, J. A. Ramos collector, in NMNH. One male paratype with same data as holotype in the author's collection.

Eurychilella cinabarina Carvalho, E. rubra Carvalho, E. figueiredoi Carvalho, and $E$. bicolar Carvalho are reddish or ornamented with red. 
Of $E$. pallida Reuter, E. fasciata Carvalho, and E. discoidalis (Reuter) only the latter has a blackish clavus. In $E$. hemiclava the black of the clavus is limited to the basal half whereas in E. discoidalis the black area

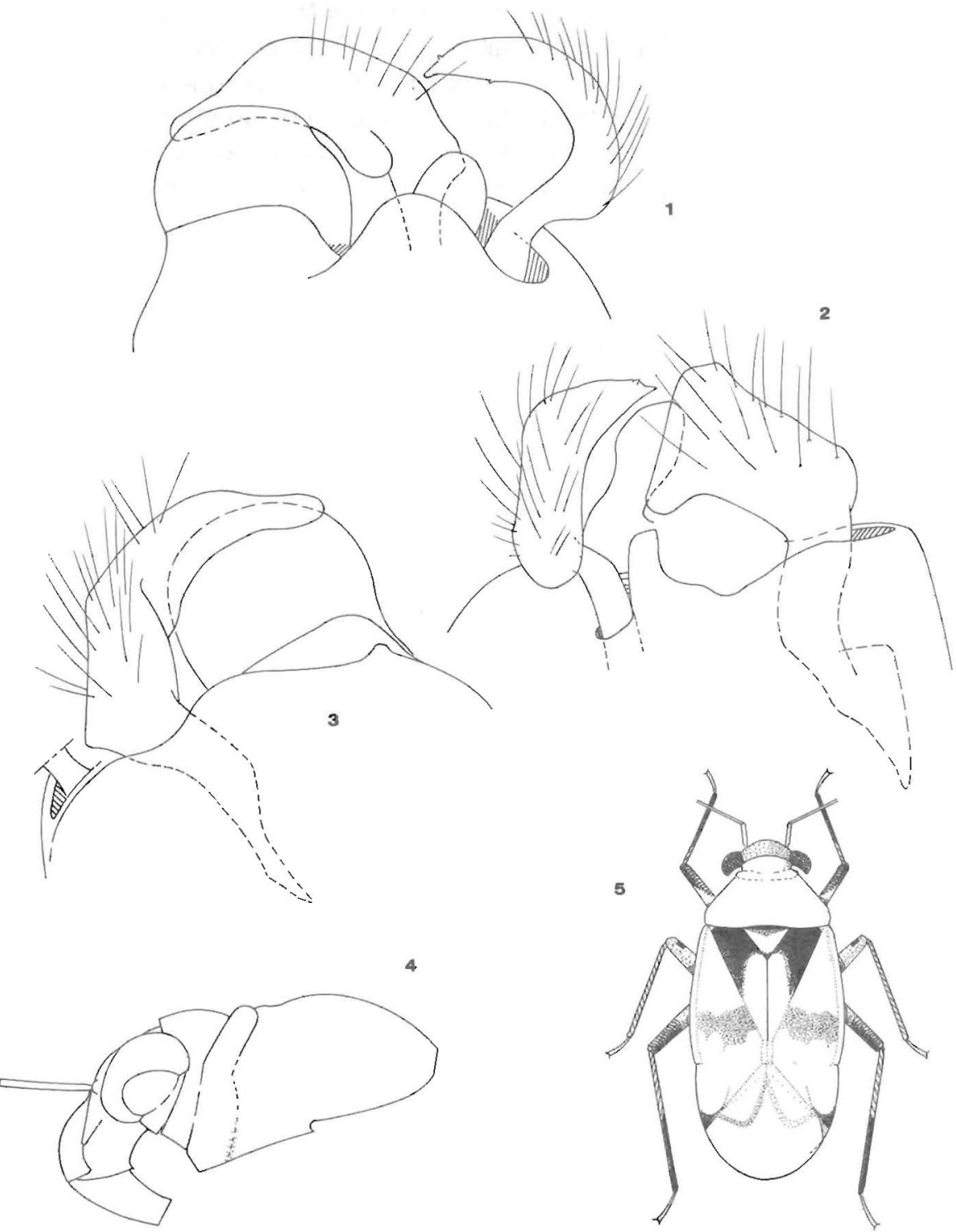

Plate I.-Eurychilella hemiclava sp nov., male, 1. Genital segments, left lateral; 2. Genital segments, ventral, apex of aedeagus omitted; 3 . Genital segments, right lateral; 4 . Head and pronotum, lateral; 5 . Habitus. 
occupies nearly the whole clavus, extends into the inner half of the corium, and basally into the membrane.

\section{RESUMEN}

Se provee una clave para separar los géneros Panamacoris Carvalho y Penha Gomes, Eurychiloides Carvalho y Penha Gomes, Eccritotarsus Stal y Eurychilella Reuter porque están aliados entre sí y porque los primeros dos, por haber sido descritos posteriormente, no están en la clave para los géneros de Bryocorinae del mundo de Carvalho (1955). Se describe Eurychilella hemiclava $\mathrm{sp}$ nov y se compara con las otras siete especies del género. 